\title{
The Academic 'Patras' of the Arab World: Creating a Climate of Academic Apartheid
}

\section{Ramzi N. Nasser and Kamal Abouchedid, Notre Dame University, Lebanon}

In this paper we adopt the term "apartheid," expanding its traditional semantic range beyond the field of race to the field of epistemology. In so doing, we wish to address three dimensions of segregation in the system of higher education in Arab countries: (1) alienation of higher education institutions from the indigenous epistemology; (2) their failure to emancipate the education they provide from the colonial past; (3) their inability to move into the modern information age. Epistemological segregation denies academics the opportunity to transform their indigenous world (Freire 1988). By identifying it and naming it, we seek to raise the alarm concerning the development of an ethos of academic apartheid in Arab institutions of higher education. We discuss the three dimensions identified above, "from a critical pedagogical perspective which illuminates the relationship among knowledge, authority, and power" (Giroux 1994: 30). In so doing, we hope to shift the analytic focus from the traditional methodological individualism of social theory - which examines power as exercised by individual decision makers (Bauman 1987)— to methodological structuralism that views power as the by-product of complex collectivist social behavior engendered by colonial forces. Further, we shift the focus from the subjective, understood as partly historically produced and regulated (Baxter 2002) and engage in a praxis that negates poststructuralist idealistic methodology, in which self-generating discourse overrides an engagement with, and understanding of, the complexities of interactions of historical 
and social systems with their institutions. In our praxis, the scholar is perceived through the roles he/she plays within a range of different, and often conflicting, discourses, and in varying historical, cultural, and social contexts. The value of methodological structuralism in analyzing the status of higher education in the context of epistemological alienation is that it can bring to light the interactive processes among the historical and sociopolitical factors that hamstring Arab academics in their efforts to become transformers of their indigenous world.

This paper can be considered a self-critical reflection on the current state of Arab academia. The fact that it criticizes the academic situation in the Arab world should in no sense be taken as implying an endorsement of the discourse of the colonizer. In this paper, we engage with a new cultural phase in the Arab world that we term "indigenous colonialism,” a condition of post-colonial trauma found mainly in Arab states. The embrace of colonial instruments by the formerly colonized results in the creation of a higher education regime controlled by an elite (patras). In this paper, the word patras refers to patriarchal elites who exercise power in absolutist, often discriminatory terms. Our aim is to combat indigenous colonialism by exposing its underlying paradigm. Scholars adopting a realist position may object that this work is not objective or "value neutral.” Our project is to deconstruct the construct of an “Arab university” in an Arab world by systematically examining its underlying paradigm. To be neutral would be to accept the frame of reference of the system of education in the Arab world, a system built on colonial principles and Western epistemologies that curtail creative emancipation. We hope that this paper will initiate a process of development of a genuinely decolonizing context, within which change can begin to be effected and resistant voices heard.

\section{Epistemological alienation}

Alienation in general may be defined as a process which treats individuals as products and objects, rather than creative actors engaged in meaningful activity (Barakat 1993). A readily discernible characteristic of Arab academics is their reliance on Western sources of epistemology, which relegates the academics themselves to the role of 
epistemological followers (or translators), rather than that of epistemological actors and creators of knowledge. A noteworthy feature of their work is the distance of academic discourse from the local context of the indigenous. In most fields where knowledge transfer occurs, the knowledge is imported, repackaged, and delivered in a secular form - a Jebel-Ali culture of academia. ${ }^{1}$ The knowledge is thus made alien to the cultural, social, and political reality of the native Arab learner. Those who arrive at some understanding of the situation, whether students or faculty, come to see that academics are marginal figures whose role in the educational process and even in their own intellectual development, is insignificant.

Currently, many European and American universities work eagerly to provide practical and authentic student-centered instruction. In contrast, the teaching in Arab universities is mostly teacher-centered and theoretical and often relies on European and American textbooks detached from the cultural contexts of the indigenous learners (Rugh 2002; Abouchedid 1994). The authors’ personal experience of discussions and research conducted with students in Arab universities is that the applicability of Western epistemology to Arab ontology is rarely debated. Attempts to shift teaching away from teacher-centered practices may lead the students to question the teacher's credentials. For example, in a sociology class, one of the authors of this paper expressed the desire to learn from his undergraduate students’ personal experiences. In response, one student said: "We are not in a position to teach you ...; we are paying tuition fees to learn, not to teach.” This attitude is characteristic of a context in which the prevailing discourse of teaching and learning is embedded in outmoded authoritarian models. However, it is not unusual to find that predominant teaching method which faculty experience in their graduate education (Even 1993) Once as students who have gone through a number of graduate courses at universities, they are used to clear objectives, lectures, and assignments provided by the instructor (Tanner, Galls, \& Pajak 1997). What is a serious condition among Arab students is a fundamentalist attitude about teaching and learning that teacher speaks-student listens.

\footnotetext{
${ }^{1}$ Jebel-Ali is a zoned area of Dubai, United Arab Emirates, to which manufacturers send their products to be redistributed bearing UAE trademarks.
} 
The very physical structure of the classroom provides a further illustration of this fact. The classroom is designed in a rigidly theatrical fashion: the teacher stands on a pedestal; the desks are arranged linearly; most classrooms have green boards and are directionally centered on the teacher. The concept of the teacher's authority so deeply engrained in students' minds coalesces with teacher-centered strategies and a teachercentered physical space in students' epistemological perspective on teaching and learning. Arab students, having been trained for obedience and respect for authority, which are characteristics of tribal behavior (Barakat 1988), are likely to detach themselves from classroom discussion for fear of challenging the "infallible" teacher. The grade book, the frigid academic discourse, and the power relations between student and teacher, combine to create an oppressive educational process. In reaction, teachers complain about their students' lethargy and lack of motivation and students complain about the authoritarian approach taken to the teaching process. Both teachers and students are caught up in a demeaning cycle of fear and distrust.

Indigenous educators who have assimilated Western discourse and non-indigenous values find it difficult to become educators who teach subject matters from an indigenous perspective that reflects the social and cultural realities of the indigenous. These educators see in indigenous epistemology a collective consciousness that deters individual effort and scholastic motivation, and these circumstances give rise to a sense of paradox and unsettledness in Arab scholars (Habashi 2005). In fact, academia in the Arab world ${ }^{2}$ emulates the tradition of higher education in the West by espousing the values of competition, individualism, and individual ownership. But in no way do these institutions establish themselves as unique indigenous cultural units espousing the collective identity of the "Arab student.” For Arab universities, the emulation of Western organization, Western culture, and the Western value of individual

\footnotetext{
${ }^{2}$ Usually the definition of the Arab World is somewhat over generalized. There are different behavioral structures in different Arab societies. For instance, Tunis, which is a predominantly a Muslim country, has instituted state rules that have enticed a behavioral structure similar to that of any Western society. However, Arab World is united by one influential cultural component, being Islam that manifests itself in every aspect of Arab social life and in specifically countries as Algeria, Bahrain, Egypt, Iraq, Palestine, Jordan, Kuwait, Lebanon, Libya, Morocco, Oman, Qatar, Saudi Arabia, Syria, Tunisia, United Arab Emirates, and Yemen. It could also include Iran but the term Arab world refers specifically to Arab countries. This paper refers specifically to Arab countries.
} 
performance is a result of a process of modernization that has often negated indigenous know-how. The inherent contradiction in this situation is heightened by the fact that the academic patras blurs the distinction between the institution as a locus for the cultivation and dissemination of indigenous knowledge and students' epistemology. It is often the case that students have to acculturate themselves to the university, which ends by being a way of colonizing the indigenous through the indigenous, i.e., through the patras.

Little is heard about indigenous scholarship by the indigenous themselves. Whereas indigenous scholars should play a major role in disseminating research on this subject and organizing fora for the discussion and exploration of ideas, most universities remain "teaching places." Private universities remain unwaveringly committed to being teaching institutions exclusively. The American University of Beirut (AUB) is a typical case. The AUB is partly bureaucratic and market oriented (Dedoussis 2004). Arab universities do little research compared, for example, to universities in Brazil. For example, in Brazil, $80 \%$ of the research budget is allocated to universities, while the rest goes to non-governmental organizations and municipal agencies (Akkari and Perez 1998). With little or no grants allocated for research, teaching loads increase to the detriment of research activity and scholarly initiative. As discussed in Nour (2006), many Arab universities in the Gulf region and along the Mediterranean coast value teaching more than research and development. The authors of this paper have taught in universities in the Gulf region as well as in Lebanon. Their experience is that chairpersons and deans who constitute the academic patras expect their faculty to teach more than five courses per semester and up to ten courses per academic year. Faculty; thus, look to course overloads as a supplementary source of income, instead of research and academic development. The academic leadership is aware of this and allocates overload based on a system of favoritism rather than merit or need. One must ask why the academic patras deter academics from undertaking scholarly activities such as research. The patras perpetuate their prestige and political authority by impeding potentially boat-rocking research, forestalling critiques within academia that might raise professional issues that would undermine the patras' position of power and control. 
Anti-research attitudes and behaviors in Arab universities are clearly reflected in the number of publications produced in Arab countries. The statistics on publishing in the Arab world are shocking. Academic journals published by Arab scholarly circles do not even number 50; in contrast, thousands of academic and scholarly journals are published in the USA alone (Nasser and Abouchedid 2001). Publishing, of course, benefits from a snowball effect. Book publishing in Arab states does not constitute a massive financial undertaking, and yet the scholarly publishing efforts of Arab states is limited, suggesting that little is done to interpret subject matter from the perspective of indigenous Arab learning needs. Generally, epistemological alienation in the Arab world persists in the absence of educational movements to overcome it. Such movements are blocked by two main sources of alienation and post-colonial social behavior.

\section{The shadow cast over the present by the colonial past}

Both private and public Arab educational institutions were established over a century ago during the colonial period. In the nineteenth century, what might be called an educational invasion by missionaries took place in the Arab Levantine in the name of humanitarian concern and the advance of science. This movement led to the establishment of a significant number of Jesuit and Protestant missionary educational institutions in former Palestine and in the part of Syria that constitutes present-day Lebanon (Szyliowicz 1973). Not only has colonial education made the course of individual development difficult for indigenous Arabs, it has also patched onto Arab schools and universities modern educational principles that are alien to most Arabs.

For example, during the nineteenth century, two kinds of schools and universities were established in what is now Lebanon. Schools of first kind were patterned after French or British educational models as a sign of solidarity and shared interests between the colonial bourgeoisie and the Arab native intellectual elite. Representatives of the Jesuit order and Protestant denominations, local Arab churches, and private shareholders have dominated the private higher education sector and sought to enable Arab students to appreciate the "Christian life” (Penrose 1970). Over the last century and since the 
beginning of this one, foreign universities in Lebanon have shed their Christian affiliations and secularized their governance. They continued to maintain Western cultural influence in this part of the Middle East. Through the "copycat” reproduction of Western modes of cognition and behavior via foreign language teaching, many French and American universities in Lebanon and the Arab world in general inculcate students with a sense of the overarching superiority of European languages, such as English and French, and implicitly promote the perception that only these languages can provide definitions of concepts and generate new theories. Schools of the second were established by proponents of Arab nationalism (Khashan 2000) and have aspired to forge a counter-colonial model of education capable of enabling the masses to throw off post-colonial subjugation. As a result, two diametrically opposed types of educational institutions have emerged: one that maintains a self-imposed pseudoisolation from Western epistemology and insulates itself from foreign ideas, and another that endorses Western education.

Western-style liberal-arts colleges for men and women have mushroomed in the Gulf region, and prestige attaches to American and British higher education degrees (Zoepf 2006b). These colleges feverishly recruit new faculty coached in the Western epistemological framework; they use English as the medium of instruction; they follow the American semester-based system; and they emulate the culture of American campuses in order to keep in line with the "international curriculum” and degree programs (Bollag 2005; Zoepf 2006b). In contrast, another group of educational institutions, established mainly in Syria, pursue a reactive counter-discourse to Western epistemology and accuse Western forms of educational systems of "being imperialist and neo-colonial and seeking to supplant Arab cultural values and destroy Arab national identities.” Syrian universities use Arabic as the medium of instruction (Del Castillo 2004), even in the teaching of the sciences, health sciences, and medicine, in order to maintain a perceived indigenous purity. Ironically, they use translations into Arabic of a Western academic knowledge base; particularly, excluding thousands of years of Arab medicine from the curriculum. 
Iraqi universities have been highly polarized under occupation by US forces. Some American universities have begun to develop programs in collaboration with Iraqi Universities (USAID, Report \#26) in the areas of agriculture, library science, research, and archeology, with a view to improving techniques of higher education. However, little effort has been made in fields in the humanities and comparative cultural studies. It should be noted that Iraqi universities have constituted a site of quiet resistance to oppression, allowing for speaking out about the occupation as well as the previous regime’s brutal policies. In Syria, the anti-colonial and ultra-national institutions have not yet succeeded in establishing a tenable alternative indigenous discourse that espouses national education with Western epistemology. Moreover, an indigenous Arab pedagogy has yet to be developed for use by the various Arab systems of education. Such a pedagogy would have to resonate with the cultural, social, and political realities of indigenous Arabs. Attempts to indigenize education have strengthened the opposition by radical groups to Western colonial models of education by motivating efforts to establish their own educational institutions and supporting resistance to the intentions and effects of a colonial epistemology. The recent setting up of Islamic universities in Egypt, Jordan, Gaza, and the West Bank (Palestine), even Indonesia and Malaysia give some semblance of constituting an Islamic revitalization movement to radicalize and indigenize education within the framework of Islamicization. Islamic educational programs go against the Western epistemological grain, implanting Islamic values of persuasion rather than exploration and putting Islamic values on a collision course with the Western cultural values. However, a number of these universities use a system’s approach coated in rationality and positivist attitudes which counters the fundamental premises of Islamic education. Consequently, Arab academics who yield to fundamentalist thinking are perhaps acting in reaction to epistemologies that make little sense to indigenous researchers (Clignet 1971): they regress to fundamentalist ideas as a way of reinvigorating the silenced past. It is thus that in many parts of the Arab world colonialism has created safe havens for the breeding of anti-Western epistemologies and the blaming of the West for meddling in Arab thinking by transplanting into it contradictory epistemologies and thoughts (Boullata 1990). 
Certainly, Western countries have interfered with the cultural, political, and economic evolution of Arab peoples, but wholesale criticism of the West misses the point. Issawi (1981), for instance, sees that intellectual and cultural stagnation accompanied by economic decline are the result of Arab evolutionary processes, mostly unrelated to Western colonialism. The Lebanese sociologist Barakat (1993) ascribes the cause of many Arab grievances to collectivist behavior, which is at the heart of the predominant value system of Arab society. Khashan (1992) considers that a highly distinctive feature of Arab collectivist behavior, characterized by patron-client interests, ultra-tribalist attitudes, continuing cultural stagnation, political oppression, over-dependence on the West, and the blatant censorship of intellectual life, is the continuing dominance of primary-group relations. Arab institutions of higher education appear almost uniformly to suffer from the same epistemological torpidity as existed under colonialism. In particular, this problem has been perpetuated by a class of neo-colonialists, the patras of Arab universities, who deny academics the freedoms of self-expression, pursuit of innovation, and critical and creative thinking. To quote Hafiz (1996, 7-8), the academic patras makes it easy for "the beasts of darkness, the enemies of the intellect and freedom" to thrive and destroy independent thinking and creativity. The absence of an indigenous course of action, Arab admiration for the Western experience of modernization, and the lack of a grassroots movement have together conduced to prevent Arab academics from taking an active role in the forging of the modern information age.

\section{Failure to move towards the modern}

The issue of modernity has been at the centre of Arab intellectual reform since the beginning of the nineteenth century. With the advent of the information age, most Arab institutions of higher education have highlighted the need to meet the functional requirements of this development. Although Arab universities are becoming organized to adapt to information technologies, their human resources do not yet have the necessary skills related to information organization and electronic education, media, and publishing to complete along these lines (Nasser \& Abouchedid 2001). Thus, information technology has been adopted as an extension of the Western information 
system, but with greater reliance on knowing how to operate than on knowing how to engage in a constructivist approach. Despite enthusiastic acceptance of, and indeed enamorment with, information technologies, very little has been done in Arab universities to transpose the indigenous printed word into an indigenous electronic medium as a platform for wider scholarly communication among Arab and Western scholars. Hence, information technology in most Arab universities functions essentially to market the institution and recruit students. Arab universities use information technology tools for learning the technique related to their particular teaching needs, while in the West, the availability of a global information network is being used to transform both the public and the private spheres and to create new social, political, economic, and cultural realities (UNDSF 2005). Within the institutions, bureaucracy operates as a source of destabilization of intellectual and academic life and development. An intensive micro-managing approach, manifested in management's involvement in trivial operational issues, inevitably discourages research and critical approaches to academia.

A recent report by Human Rights Watch (2005) indicates that the academic leadership often drains academics’ energy with inconsistencies, capricious decisions, ${ }^{3}$ and whimsical regime changes. Whereas, academic freedom broadly thrives in American universities, in Beirut and Cairo the idea that academic freedom is inherent to academic life is unheard of: academic freedom is treated as a perk rather than a given in academic life (Human Rights Watch Report 2005). The patras deploys an internal network of spies and informants to serve them and undermine academics who wish to pursue their scholarship, responsible and free speech, and innovative teaching methods. Arab scholars are induced to turn their backs on their role as social transformers, critical thinkers, and agents of social change. They cannot marshal adequate support for their initiatives to liberate academia from institutional coercion and nepotism, and they play

\footnotetext{
${ }^{3}$ This is typified by the recent firing on February 2006 at Zayed University, in the United Arab Emirates, of an American professor, Claudia Kiburz, who taught English, and of her supervisor, Andrew Hirst, who heads the university's English Language Center (Zoepf, 2006a). Ms Kiburz shared the now infamous Danish newspaper cartoons with her students for purposes of class discussion. The firing exemplifies how insubstantial is the respect for academic freedom in one of the most socially liberal Gulf nations. Ironically, after this incident, the cartoons were widely circulated and discussed on campus (Zoepf 2006b).
} 
little part in policy-making or decision-making. Despite all these obstacles, independent, critical, research-oriented Arab scholar-researchers do exist: they relentlessly challenge the politics of the system, but they are overloaded with administrative and teaching tasks, rebuffed, or recruited into small paternalistic and patriarchal circles, such that their radical motivation and their desire for change dissipate. A strong board of directors that exerts control by providing large amounts of money to a university in the form of philanthropic donations can fetter even an administration that would otherwise be supportive of the university's scholars. The absence of controls on the requirements made of faculty and the vagueness of performance expectations make for little sense of commitment within the organization as a whole. Thus, academics place little value on their own academic output, whether in the form of instruction, research, or administrative tasks. The debilitating impact on Arab characterize higher education creates an epistemological vacuum, such that academics cannot help placing even the most burning scholarly issues at the bottom of their list of intellectual life made by the "clanocracy,” patriarchal practices, and nepotism that priorities, however painful this may be for them. ${ }^{4}$

The university patras can be characterized as revivers of Western artifacts and reproducers of colonial knowledge. Intimidated by Western knowledge and technology, they reject Arab indigenous know-how and helplessly rely on Western expertise in implementing educational and technol ${ }^{3}$ ogical programs. Consequently, Arab universities hinder the promotion of indigenous Arab knowledge by sidelining academics and engaging them in administrative and teaching tasks. Universities in other transition countries, whose constitutional elements edge toward market-style fundamentals, for instance India, have adopted a contrary course of action. There, academics take their work in their respective fields of specialization seriously. They nationalize local problems while rejecting foreign interference and research on local and indigenous issues by foreign entities (Barnes 1982). Similarly, in Latin America, in

\footnotetext{
${ }^{4}$ The word clanocracy uses clan instead of "bureau” as conceptualized in Max Weber's notion of bureaucracy. Clanocracy refers to clan social practices in organizing social affairs in their tribal context (El-Amine 1998).
} 
rural areas, a grassroots movement has replaced the development programs established by the United Nations in conjunction with local institutions and universities. These programs had long sidelined more indigenous local programs that met the immediate needs of society (Schaw and Grieve 1979).

\section{Social degradation and structural deficiencies in higher education}

Academia has grown significantly in the Arab world with the sprouting of colleges and universities in the Gulf region. This has not, however, improved the quality of Arab undergraduates and graduates. In fact, what we have seen is a major turnaround in the quality of graduates. The fact that most of these institutions behave more like businesses than institutions of higher education produces a transactional approach to education geared more to student stupor than to instilling ideals of excellence. This state of affairs can be ascribed not just to economic causes, but also to social ones: the development of a large middle class, and, along with it, the establishment of institutions of higher education and of a modern service structure. The economic calculation of the return on education on the micro level ignores the macro economic return: since, with the rising cost of education, the benefit-cost ratio is less than one (the internal rate of return is considerably less than what students’ parents invest), the recouping of the educational investment takes longer in Arab countries than it does for students in the USA, England, or Canada (Fergany 2001). So rather than viewing higher education as a benchmark in upward mobility, many perceive it as a stepping-stone to prestige or high status. Thus, in the Arab world, education constitutes a means of filling a social need more than an economic one. Possibly because of this epistemology, education is seen as a commodity rather than as a personal lifelong experience. To many, this commodity seems lucrative and productive of revenues, as it can be sold or bought for a price.

In the Arab context, the licensing of programs is a means of obtaining university accreditation. Once a university has been licensed to operate programs by the various governmental ministries, it may wish to do as it likes in changing the substance of the curriculum and in so doing faces little interference by officials in the ministry of higher education. However, substantial numbers of universities now seek accreditation from 
foreign associations in order to market themselves as the sole credible academic institutions in the Arab world. They may turn a blind eye to the mishandling of finances and they invest heavily in faculty who have doctorates, facilities, programs, and technology, all in order to receive the foreign rubber stamp while the whole time, organizationally, corruption drives even the simplest student transactions.

A number of universities in the Arab world vie with each other to establish affiliations with sister universities in the West. This is the situation that has obtained in the establishment of the Knowledge City in Dubai and the Education City in Qatar (Zoepf 2005). In these two Gulf region locations, Tier I universities have formed ties with Arab institutions, whose doors are then opened to local Arab students. This relationship has had some very disturbing results. The universities in question use their affiliations to market themselves as American or British institutions, and they coordinate their programs with their partner universities abroad. But the Arab universities in question are far from implementing the kinds of organization, the culture, or the values that most American universities enjoy (Dedoussis 2004). Many of these universities carry the American label in order to project an appearance of value-added to prospective students. In reality, and disturbingly, they are very parochial entities, undermined by confusion of identity and operating in a constant state of epistemological quandary.

In many cases, colleges and universities in Lebanon and the United Arab Emirates and other Gulf states operate with non-existent infrastructure for higher education. Recently, Western academics who have taught in the Gulf region have alleged these institutions are more like warehouses (see “Dave’s ESL Forum: An Internet Discussion Forum”) or fronts for dubious business establishments. Many of these universities receive their licenses through corrupt arrangements between the university administration and the top echelons of their countries' ministries. They graduate students with mediocre or substandard qualifications and continue to operate under the protective wing of ministries of higher education. The alliance of private institutions and local governance conveys the impression that no external national body can protect faculties' inherent rights. It also plants the seeds of fear in Arab academics and 
continues to be a factor militating against success in the effort to free Arab academic life from the dark forces of stagnation.

The structure of Arab society is deeply influenced by the patriarchal power and patronclient dynamics that trickle down from the top echelons to junior-level faculty and staff. Academics who refrain from engaging in dubious interactions run the risk of being derailed from their promotional track, and even being dismissed altogether. Serious academics see all this with mounting dismay. Their efforts at exploring truth and studying the nature of society are neutralized by a system pervaded with inadequacies, a dysfunctional atmosphere, and unethical practices.

\section{What is to be done? Conclusion and recommendations}

Academia in the Arab world must have recourse to the globalutionaries ${ }^{5}$ of the Arab world, peaceful and pragmatic professionals who do not seek revolutionary change but make use of non-profit global institutions to make their case heard. Globalutionaries often bring change by turning to international accrediting agencies, since many Arab universities measure quality through the types of external accreditation they qualify for. Academics can receive support from these accrediting bodies because such bodies oblige the academic and administrative leadership to operate with greater accountability, transparency, and respect for faculty rights, regulations, and rules. Universities in their current state cannot make the necessary corrections on their own. Much more is needed for external independent bodies to become involved with local academics and civil society in the fight for an ethical, professional, and correct practice.

Academic leadership, faculty, and staff must all understand the judicial process and the role of civil society in the development and significance of a university. Disciplinary processes must take their course, and legal procedures must be set in motion to hold academic entities responsible and accountable for their actions. The leadership should

\footnotetext{
${ }^{5}$ Globalutionaries a word coined-up by Thomas Friedman of the New York Times (1997), and refers to individuals who attempt to do everything they can to integrate into the global economy, on the conviction that the more their nations are tied into the global system, the more their governments and institutions will be exposed to the rules, standards, laws, pressure, security and regulations of global institutions, and, at the same time, the less arbitrary, corrupt and autocratic national systems will be.
} 
provide mentoring, guidance, and conflict resolution strategies (Bass and Steidlmeier 1999). Leaders must be of a caliber to be able to forge a platform for intellectual discovery and epistemological emancipation from over-politicized students and university-wide bad practices. Once a committed body is established, it will initiate the drive for positive development, trust, and respect (Gardner and Cleavenge 1998). Faculty should be able to see that their leadership is capable of dealing with seemingly mundane tasks imbued with a higher purpose. They should feel that leadership devotes effort to preserving what is morally correct. Both faculty and the academic leadership can create the building blocks with which to effect the correction of the institution and prepare the basis for the fermentation of a powerful collective identity, through which value is given to individual output for the sake of the collective good. The depoliticization of the university is one of the most difficult tasks that academic leadership will have to carry out by winning respect, inspiring others, and promoting empowerment. Only then can faculty in turn sow the seeds of change among their students, within the culture, and in the society and the university at large (Conger 1999).

The judicial process must be taken seriously, such that the rule of law is strengthened and patron-client relations, favoritism, and kickback systems are combated by strong regulations. The leadership and academics alike must understand the seriousness of their actions. Decisions, understood by all, must be made by a body that is accountable and can hold academic personnel to a legal framework that ensures there are serious ramifications for wrong-doing. Once the sense of professional/academic correct practice is institutionalized, a careful look at scholarly and indigenous values could bring higher education closer to emancipation from the Western impress on indigenous frameworks of academic expression.

Relying on critical theory in education, which is concerned with the workings of power in and through pedagogical discourses, the analyses presented in this paper relate social and epistemological conditions, including post-colonialism, to academic decline in the Arab world. We have explored the resistance to epistemological renovation, and to the 
incorporation of new indigenous principles in the structures of institutions of higher educational. Institutional, clanocratic, and nepotistic behavior stifle efforts by academics to alter the status quo with respect to indigenous epistemology. The ruling academic elite (the patras), with their nepotistic and clientelistic behavior, violate the fundamental tenets of academic freedom and creativity (Sabour 2001). Institutions of higher education must be emancipated from Western epistemological thinking. Our intention has not been to place the responsibility for academic failure on indigenous Arab academics. The cultural capital of the colonizers has derailed the indigenous from their own educational course, and the transfer of Western epistemology to the indigenous has had an impact on what is learned or not learned in the Arab world. What is now happening is that schooling is creating a generation of internalizers but not producers, a trend that warns of the negative effects of schooling on students' identity formation. The process of emancipation from the colonial past and from the overwhelming influence of Western epistemology must start with a cultural movement capable of reinvigorating the indigenous Arab epistemology.

Colonialism has a palpable influence on social relations both within a nation and between nations. It tends to concentrate power in the hands of a few. The educational institutions of the Arab world were conceived to serve that few, leaving the great majority behind. Scholars within universities must reflect on the purpose of education and the role it plays for the wider community. Although the market-oriented approach of universities in the Arab world fosters the desire of the majority of Arab students to receive a Western form of education, students remain passive in the face not only of the reality of the demographics of Arab states, but also of epistemological educational issues. As well, recent times have been revolutionary in terms of knowledge transfer, given rapid technological developments coupled with economic and social globalization. Yet Arab scholars remain excluded, or exclude themselves, from access to the global knowledge structure. Further, these scholars have done little to transform the power dynamic within the pedagogical relationship between student and teacher and indeed between student and material. Unless the idea of reforming the Arab university by an accountable and democratic process takes hold—moving the Arab university 
from the status of object (passive actor) to a perceived status as actor/subject (critical actor) (Illich 1973) and restructuring the Arab university classroom (i.e., such that power relations are altered) — the Arab university, far from playing the role of paradigmatic agent of social change, will remain subject to the forces of stagnation and underdevelopment.

\section{Reference List}

Abouchedid, K. 1994, 'The Text and the Significance of the Context,'Sci-Quest, vol. 4, no. 1, 35-38. Akkari, A. and Perez, S. 1998, 'Educational Research in Latin America: Review and Perspectives,' Education Policy Analysis Archives, vol. 6. Available: http://olam.ed.asu.edu/epaa/

Barakat, H. 1993, The Arab World: Society, Culture and State, University of California Press, Los Angeles.

Barnes, J. 1982, 'Social Science in India: Colonial Import, Indigenous Product, or Universal Truth,’ in Indigenous Anthropology in Non-Western Countries, ed. H. Fahim, 19-33, Carolina Academic Press, Durham, North Carolina.

Bass, B. M. and P. Steidlmeier 1999, 'Ethics, Character, and Authentic Transformational Leadership Behavior,' Leadership Quarterly, vol. 10, 181-217.

Bauman, Z. 1987, Legislators and Interpreters: On Modernity, Postmodernity and Intellectuals, Stanford University Press, Stanford

Baxter, J. 2002, 'Competing Discourses in the Classroom: a Post-Structuralist Discourse Analysis of Girls' and Boys' Speech in Public Contexts,' Discourse Society, vol. 13, 827-842.

Bollag, B. 2005, 'American Accreditors Go Abroad,' The Chronicle of Higher Education vol. 52, no.5, A36.

Boullata, I. 1990, Trends and Issues in Contemporary Arab Thought, State University of New York Press, Albany.

Clignet, R. 1971, 'Damned if You Do, Damned If You Don't the Dilemmas of Colonizer-Colonized Relations,' Comparative Education Review, vol. 15, 296-312.

Conger, J. A. 1999, 'Charismatic and Transformational Leadership: An insider's Perspective on These Developing Streams of Research,' Leadership Quarterly, vol. 10, 145-179.

Dedoussis, E. 2004, 'A Cross-Cultural Comparison of Organizational Culture: Evidence from Universities in the Arab World and Japan,' Cross Cultural Management, vol. 11, 1533.

Del Castillo, D. 2004, 'The Arab World's Scientific Desert,' The Chronicle of Higher Education, vol. 50, no. 28, A38.

El-Amine, A. 1998, Higher Education in Lebanon, Lebanese Association of Educational Studies, Beirut Lebanon.

Even, R. 1993, 'Subject-Matter Knowledge and Pedagogical Content Knowledge: Prospective Secondary Teachers and the Function Concept', Journal for Research in Mathematics Education, vol. 24, no. 2, 94-116.

Fergany, N. 2001, Higher Education in Arab Countries; Human Development and Labour Market Requirements, Almishkat Centre for Research, Egypt

Foucault, M. 1980, Power/Knowledge: Selected Interviews and Other Writings 1972-1977, Pantheon, New York.

Friedman, T. 1997, 'The Globalutionaries,' The New York Times, 24 July

Gardner, W. L. and D. Cleavenger 1998, 'The impression management strategies associated with transformational leadership at the world-class level,' Management Communication Quarterly, vol. 12, 3-41.

Giroux, H. A. 1994, Disturbing Pleasures: Learning Popular Culture, Routledge, New York. 
Hafiz, S. 1996, Arabs Without Anger, Dar Al Nafa’is, Beirut.

Habashi, J. 2005, 'Creating Indigenous Discourse, History, Power and Imperialism in Academia, Palestinian Case,' Qualitative Inquiry, vol. 11, no. 5, 771-788.

Human Rights Watch 2005, Reading Between the 'Red Lines': The Repression of Academic Freedom in Egyptian Universities. Human Rights Watch Report, 17 (6). Available: http://hrw.org/reports/2005/egypt0605/

Illich, I. 1973, Deschooling Society, Penguin, Harmondsworth.

Issawi, C. 1981, The Arab’s World Legacy, Princeton: NJ: Darwin Press.

Khashan, H. 1992, Inside the Lebanese Confessional Mind, University Press of America, Boston. 2000, Arabs at the Crossroads: Political Identity and Nationalism, University Press of Florida, Gainesville.

Nasser, R. and Abouchedid, K. 2000, 'Educational Research in the Levantine: Revisited,' Palma Research Journal, vol. 7, 43-60. 2001, 'Problems and Epistemology of Publishing in the Arab World: The case of Lebanon,' Journal of Electronic Publishing, vol. 6, 1-12.

Nour, S. 2005, 'Science and Technology Development Indicators in the Arab Region: A Comparative Study of Arab Gulf and Mediterranean Countries,' Science, Technology, and Society, vol. 10, no. 2, 249-274.

Penrose, S. 1970, That They May Have Life: The Story of the American University of Beirut, The American University of Beirut Press, Beirut.

Sabour, M. 2001, The Ontology and Status of Intellectuals in Arab Academia and Society, Aldershot Hants, Ashgate..

Schaw, T. and Grieve, M. 1979, 'Dependence as an Approach to Understanding Continuing Inequalities in Africa,' The Journal of Developing Areas, vol. 13, 229-246.

Szyliowicz, J. 1973, Education and Modernization in the Middle East, Carnel University Press London.

Tanner, C., Galls, S., and Pajak, E. 1997, 'Problem-Based Learning in Advanced Preparation of Educational Leaders,' Educational Planning, vol. 10, no. 3, 3-12.

United Nations, Digital Solidarity Fund 2005, From the Digital Divide to the Need for a World Wide Solidarity Movement, United Nations, New York.

Weidemann, W., and Humphrey, M. B. 2002, 'Building a Network to Empower Teachers for School Reform,' School Science \& Mathematics, vol. 102, no. 2, 88-93.

Zoepf, K. 2005, 'In Qatar’s Education City, U.S. Colleges Build Atop a Gusher,' The Chronicle of Higher Education, vol.51, no. 33, A42 2006a, 'U.S. Professor is Fired Over Cartoons by University in United Arab Emirates', The Chronicle of Higher Education, vol. 52, no. 25, A41. 2006b, 'Universities for Women Push Borders in Persian Gulf,' The Chronicle of Higher Education, vol. 52, no. 32, A46 